\title{
Apartheid in the Holy Land: Theological reflections on the Israel and/or Palestine situation from a South African perspective
}

\begin{tabular}{|c|c|}
\hline \multicolumn{2}{|l|}{$\begin{array}{l}\text { Author: } \\
\text { Jerry Pillay }{ }^{1}\end{array}$} \\
\hline \multicolumn{2}{|c|}{$\begin{array}{l}{ }^{1} \text { Department of Church } \\
\text { History and Church Polity, } \\
\text { Faculty of Theology, University } \\
\text { of Pretoria, South Africa }\end{array}$} \\
\hline \multicolumn{2}{|c|}{$\begin{array}{l}\text { Project leader: J. Pillay } \\
\text { Project number: } 04653484\end{array}$} \\
\hline \multicolumn{2}{|c|}{$\begin{array}{l}\text { This research is part of the } \\
\text { project, 'African Christianity } \\
\text { and Development', directed } \\
\text { by Prof. Dr Jerry Pillay, } \\
\text { Department of Church History } \\
\text { and Church Polity, Faculty of } \\
\text { Theology, University of } \\
\text { Pretoria, South Africa }\end{array}$} \\
\hline \multicolumn{2}{|c|}{$\begin{array}{l}\text { Corresponding author: } \\
\text { Jerry Pillay, } \\
\text { jpillay@up.ac.za }\end{array}$} \\
\hline $\begin{array}{l}\text { Dates: } \\
\text { Received: } 12 \\
\text { Accepted: } 13 \\
\text { Published: } 18\end{array}$ & $\begin{array}{l}\text { Apr. } 2016 \\
\text { June } 2016 \\
\text { Nov. } 2016\end{array}$ \\
\hline \multicolumn{2}{|c|}{$\begin{array}{l}\text { How to cite this article: } \\
\text { Pillay, J., 2016, 'Apartheid in } \\
\text { the Holy Land: Theological } \\
\text { reflections on the Israel and/ } \\
\text { or Palestine situation from a } \\
\text { South African perspective', } \\
\text { HTS Teologiese Studies/ } \\
\text { Theological Studies 72(4), } \\
\text { a3434. http://dx.doi. } \\
\text { org/10.4102/hts.v72i4.3434 }\end{array}$} \\
\hline \multicolumn{2}{|c|}{$\begin{array}{l}\text { Copyright: } \\
\text { (c 2016. The Authors. } \\
\text { Licensee: AOSIS. This wor } \\
\text { is licensed under the } \\
\text { Creative Commons } \\
\text { Attribution License. }\end{array}$} \\
\hline \multicolumn{2}{|l|}{ Read online: } \\
\hline 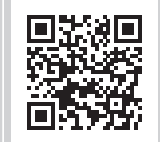 & $\begin{array}{l}\text { Scan this QR } \\
\text { code with your } \\
\text { smart phone or } \\
\text { mobile device } \\
\text { to read online. }\end{array}$ \\
\hline
\end{tabular}

I first attempt to draw a comparison between the Israel-Palestine conflict and the South African experience of apartheid. Drawing on other established sources and personal experience, I conclude that, while there may be some differences between the two contexts, in essence, the similar experiences of colonialisation and racialisation makes the apartheid comparison compellingly relevant. I then proceed to theologically explore the themes of justice and reconciliation and what it may mean in the context of Israel-Palestine whilst extracting from the South African experience. The article also offers some reflections on the role of the Church in addressing the Israel-Palestine conflict.

\section{Introduction}

The central thesis of this article is that the Israel-Palestine situation shows great resemblances to the experience of apartheid in South Africa which can be seen in the colonisation, the war and the forced displacement of people in Palestine. This article attempts, firstly, to show this apartheid comparison and then proceeds to discuss the theological implications of the issues of justice and reconciliation in Israel-Palestine by referring to the same in the South African context. Drawing from the South African experience, the article also offers some reflection on the role of the Church in the Israel-Palestine context.

\section{The apartheid analogy}

The word 'apartheid' comes from an Afrikaans word meaning 'apartness' or 'separateness'. Many white South Africans who attempt to defend 'apartheid' usually speak of separate development which tends to give a positive connotation to the word. However, it is actually an official policy of racial segregation, involving political, legal and economic discrimination against 'non-white' people. It is a policy or practice of separating or segregating groups. This policy separated white and non-white people in South Africa from 1948 to 1994. Black people had to carry special papers or have permission to live and work in particular areas. Many laws were made that prevented mixed marriages, and black people could not own land in white areas, vote or use the same public facilities as white people. Public toilets, parks, beaches and recreational facilities were restricted in certain areas for white people only; black people would be arrested if they tried to use these facilities.

During the 19th century, the Jewish leadership was partially to influence European nationalism and colonisation (cf. Hussein Al-Rimmawi 2009:375-412). They shared a common desire to establishing the State of Israel on the land of Palestine. This became the paradigm for the foundation of the Israeli state which exists up to this day with great cost to human rights and lives. The Palestinians continue to fight for their independence in the face of Israel's continuation to take Palestinian land.

Hence, the analogy between Israel and apartheid ${ }^{1}$ entails a comparison between Israel's treatment of the Palestinians and South Africa's treatment of non-white people during its apartheid era. ${ }^{2}$ The analogy is not new. It has been used by scholars, United Nations investigators, human-rights

\footnotetext{
1.The word 'apartheid' is today used quite broadly. For example, the gap relationship between the Global North and South, economic discrimination, are described as apartheid, but the term really emerged from the experience of colonisation and racialisation in South Africa.

2.Note John Dugard's (2008:13), a special rapporteur on human rights, comment: 'What is happening in the Palestinian territory is that Israel is practicing apartheid but in a very dishonest and concealed manner. At least South African apartheid was open and honest. There were notices to indicate that certain facilities were for blacks and certain facilities were for whites only. In Israel you cannot easily access the law. You just have to take it from some member of the IDF that this is the law for a particular day.'
} 
group and critics of Israeli policy, including Jewish critics and others whose identities fall between and/or outside of these groupings (Cliff 2000:9; Davis 2001; Pollak 2009; Rodinson 1973; Will 2007:412). For example, in 2007, a UN report stated that ' $[e]$ lements of the Israeli occupation constitute forms of colonialism and apartheid, which are contrary to international law' and suggested that the 'legal consequences of a prolonged occupation with features of colonialism and apartheid' be put to the International Court of Justice. ${ }^{3}$ In 2009, the Human Sciences Research Council of South Africa published a 300-page report (Bakan \& Abu-Laban 2009) which stated the following:

The State of Israel exercises control in the fOccupied Palestinian Territories $\}^{4}$ with the purpose of maintaining a system of domination by Jews over Palestinians and that this system constitutes a breach of the prohibition of apartheid. (p. 338)

In March 2011, Richard Falk (2014), special reporter with the UN, said:

The continued pattern of settlement expansion in East Jerusalem combined with the forcible eviction of long-residing Palestinians is creating an intolerable situation ... (and) can only be described in its cumulative impact as a form of ethnic cleansing. (p. 141)

Of course, opponents of the analogy claim that the comparison is factually, morally and historically inaccurate and intended to delegitimise Israel. Opponents state that the West Bank and Gaza are not of the sovereign Israel. Although the internal free movement of Palestinians is heavily regulated by the Israeli government, the territories are governed by the elected Palestinian Authority and Hamas leaders so they cannot be compared to the internal policies of apartheid South Africa. Opponents to this view also state that, unlike the South African context that was explicit about its racial segregation policies, Israeli law is the same for Jewish citizens and other Israeli citizens with no explicit distinction between race, creed or sex. For example, South African Judge Richard Goldstone, a Jew, states that the charge that Israel is an apartheid state is a false and malicious one that precludes rather than promotes peace and harmony. For example, Goldstone wrote in the New York Times that the term 'apartheid' is an unfair and inaccurate slander against Israel, calculated to retard rather than advance peace negotiations (Goldstone 2011).

That said, according to the findings of the South African session of the Russell Tribunal, the key word to describe Israeli practices in occupied Palestine was 'apartheid,' at

\footnotetext{
3.Significantly in response to these realities, the contemporary civil-society movement for boycott, divestment and sanctions (BDS), Israel has similarly popularised the notion of 'apartheid' in reference to Israel (Bakan \& Abu-Laban 2009).

4.'Occupied Territories' is the Palestinian name for the parts of the West Bank and Gaza Strip occupied by Israel. It is territory under the control of a belligerent armed force, not being administered pursuant to peace terms, treaty or other agreement. the term 'occupation' is employed in the context of the Israelin Palestinian conflict the a the ar Tume the the Palestinians. The term is also used as part of a general assault upon Israel's legitimacy in the context of a geopolitical narrative that has little to do with Israel's status as an occupier under international law.
}

least in terms of international law. The findings argue that apartheid's 'legal definition applies to any situation anywhere in the world where the following three core elements exist: (1) that two distinct racial groups can be identified, (2) that 'inhuman acts' are committed against the subordinate group and (3) that such acts are committed systematically in the context of an institutionalised regime of domination by one group over another (Harlow 2013:95.3). It is fairly clear that this is the case in the Israel-Palestine situation. The consequent colonisation, racialisation and stereotyping of the Arab 'other' that has marked the Palestinian population demands an analysis of patterns of racialisation (Bakan 2009:332). The application of the term apartheid, meaning state-sponsored 'separateness of 'races', is consistent with the racial contract framework and draws attention to the exclusionary and violent character of the Israeli Zionist project regarding the indigenous Palestinian population. ${ }^{5}$ In fact, most proponents of the one-state solution frame their arguments with reference to or in the context of a challenge to an apartheid-like system (Abunimah 2005; Cook 2006; Davis 2003; Farsakh 2002, 2005; Karmi 2007; Tilley 2005). It is our opinion then that, given the state of practices of systemic differential treatment based on racialised and ethnicised characteristics that affect citizenship and rights, the apartheid analysis has significant empirical validity in the case of IsraelPalestine. Admittedly there may be differences in the analysis of these contexts, but by and large, we see the same disrespect and disregard for human dignity and rights, the same use of the law to demonise and brand others as 'terrorists' and refuse people's rights to adequate economic and educational opportunities as well as the persistent use of the settler mentality which can be compared to the Zionist project and the building of the Apartheid Wall that continues to separate Israeli and Palestinian people.

In December 2012, I was amongst a group of leaders of various churches and church organisations (including women and youth) in South Africa that visited the Holy Land to gain first-hand experience of the Israel-Palestine situation. We were invited to listen to the stories and perspectives of what is happening in Palestine. As we listened to the different sides of the stories shared by church leaders, Muslims, Jews, political representatives, NGOs, soldiers and ordinary local people concerning the situation in Palestine, we were starkly reminded of the apartheid days in South Africa and bemoaned the fact that there seemed to be nothing really holy about the Holy Land. Yet we were encouraged by the initiatives undertaken by Christians, Muslims, Jews and others to find peaceful solutions to the problems of Palestine and Israel.

Mindful of our own history and the ongoing need for healing, reconciliation and peace, we were able to identify and engage with certain experiences in a deeply meaningful and personal way. We also recognised with sadness our own sense of judgment and complicity as Christians in 
addressing the realities of God's people in this part of the world - often out of ignorance and because of misleading information and untested beliefs. It is for these reasons that we went back and shared with the South African public and Christians in particular what we heard, encountered and discerned together during this journey with our friends in Palestine and Israel. I now wish to share with you some of our personal experiences which enabled the visiting team, and I may add that they were mostly black South Africans, to conclude that what we encountered was nothing short of the apartheid that we experienced in South Africa. ${ }^{6}$ I was especially surprised and moved when my fellow black colleagues from South Africa went even further and said that it was worse than they had seen or experienced in South Africa.

In our days in Palestine and Israel, we saw the following for ourselves which can be compared to the apartheid experience in South Africa:

1. They are building infrastructure to reinforce an apartheid system, for example, separate roads for Palestinians and Israelis and especially the wall which brings limited security to Israelis but ultimately steals land, oppresses and separates Israelis and Palestinians from each other. This was also evident in South Africa in which the majority of black people were deprived of their land. The minority white population occupied more than $85 \%$ of the land. The implementation of the Group Areas Act essentially prevented black people from living on the land forcibly occupied by the apartheid regime.

2. The different kinds of checkpoints and blockages humiliate, harass and oppress Palestinians psychologically, politically and economically. We were deeply alarmed that foreigners were accorded a far easier passage of travel from one place to another than the Palestinians in their own land. This, too, was the case in South Africa. Local people were not allowed the freedom of travel whereas foreigners could go wherever they wanted. The scars of these experiences are still very prevalent amongst those affected in South Africa.

3. Young Israeli soldiers are used to uphold the military occupation of Palestine. This included some former South African young Jews with whom we had the privilege to speak. The South African government back then depended on the military to sustain the apartheid policy, often using even black people against one another. For example, black policemen were used to arrest those who resisted apartheid or transgressed the apartheid laws.

4. Israeli settlements in Palestinian territories are in direct violation of international law, depriving Palestinians of land, natural resources and freedom. Apartheid in South Africa, indeed, violated international law, and it was the international pressure that finally forced it into submission.

5. Christians are working together in addressing the issues of the occupation. This is evident in the Karios Palestine

6.See Farid Esack's (2008:10) account of his own experience in very descriptive comparison with South Africa where he states that the Israel-Palestine situation is worse. initiative and in their broad involvement in non-violent resistance to the occupation. The churches in South Africa united to resist the common enemy: apartheid.

6. Christians and Muslims are praying and working together on practical matters to end the occupation. In South Africa, one of the greatest movements against apartheid was the interfaith and ecumenical efforts. It was the involvement and mobilisation of these religious groups that eventual saw the demise of apartheid.

7. The destruction and demolition of homes is, inter alia, incited by the intention to dispossess Palestinians of their land, resulting in a broader picture of ethnic cleansing.

8. The economic impact of the occupation is seen in the following: businesses abandoned because of the wall and blockages, the doors of shops wielded and closed, olive fields destroyed, restrictions on movement and the emergence of ghost towns in what used to be thriving communities. Of course, in the South African context, business could never really prosper and the economy could never really develop because only white people were actually allowed to advance in this way.

9. Believers are restricted and/or prohibited from worshipping and visiting places of religious importance to them. In South Africa, believers were not really allowed to join in worship together because of the Group Areas Act, but many churches defied this at times.

10. Water tanks on the roofs of Palestinian homes are evidence of restrictions on the use and provision of water whilst this was noticeably absent from homes in the Israeli settlements. In the South African context, the areas in which the majority of black people lived did not have electricity, water or proper sanitation facilities. The areas were disadvantaged and deprived in favour of others by the apartheid policy.

11. In spite of the resentment and even hatred, we saw signs of hope, resilience and the tenacity of the human spirit in the face of injustice and oppression as well as commitment to a just peace. In this regard, the message of love for the enemy too, albeit expressed in non-violent resistance in the Karios document, is a sterling example of the Gospel of Jesus Christ. This, too, was evident in the townships in South Africa. I was often amazed at how people could dance and sing in the midst of oppression, hunger and dehumanising circumstances brought about by the apartheid regime.

12. The arrogance, blindness, insensitivity, self-destruction and illusions of security of the oppressor in the establishment of settlements and the use of military might were noticeable. When things got out of hand in South Africa, the apartheid regime declared 'a state of emergency' and used the might of the law and the military to sustain its policies.

I mentioned the above to further illustrate the comparison between apartheid Israel and apartheid South Africa. The above points are intended to illustrate this more clearly and factually. In sharing these personal experiences, it is important to point out that, coming from South Africa, this was a deeply 
painful and emotional experience as we resonated with our own struggles under the apartheid regime. Apartheid was a 'racial enclave policy', manifested in white domination and the oppression of blacks by the creation of the black homelands (Bantustans). The incidents of population transfer, military occupation, nominal self-governance, travel restrictions, residency revoking and the prevention of family unification are all cited as mirrors of what Israel imposes on the occupied territories. As the apartheid regime in South Africa, Israel justifies these measures under the pretext of 'security'. As a Human Science Research Council (HSRC) report (May 2009:17) puts it: 'contrary to such claims, they are in fact part of an overall regime aimed at preserving demographic superiority of one racial group over the other in certain areas.'

South Africa's legend and world icon, Nelson Mandela, knew this, and therefore he stated already in 1997 (BDS 2013:1):

The United Nations took a strong stand against apartheid; and over the years, an international consensus was built, which helped to bring an end to this iniquitous system... but we know too well that our freedom is incomplete without the freedom of the Palestinians.

Mandela (BDS 2013:2) further compared the situation of Palestine with that of South Africa: 'The histories of our two peoples, Palestinian and South African, correspond in such painful and poignant ways.' He mentioned in 1990 (BDS 2013:2): 'We [South Africans and Palestinians] live under a unique form of colonialism in South Africa, as well as in Israel, and a lot flows from that.' 'Just like ourselves they [the Palestinians] are fighting for the right to selfdetermination'(ibid). In the minds of many South Africans who have studied, reflected on and experienced the situation in Israel and Palestine, there is this close comparison between that context and the apartheid experience in South Africa, if not worse.

\section{Theological themes}

I shall now turn my attention to theological themes in addressing the situation in the Israel-Palestine situation. Admittedly, there are many theological themes that can be explored in this context such as sin, judgment, creation, humankind, peace and human dignity. However, it is not within the scope of this paper to engage such a wide theological analysis. I shall therefore limit my discussion to theological reflections on justice and reconciliation. My selection of the latter is for the following reasons: 1) Both have been identified as important themes in the struggle against apartheid, 2) they are also significant themes in the Israel-Palestine context, and 3) in a sense, most of the other theological themes are embraced in these two. Even here, I shall draw some comparisons with South Africa whilst acknowledging that the context is different. Nonetheless, it can be compared to a similar apartheid experience which has been addressed in the above section.

\section{Justice}

Justice $^{7}$ is a very significant theological theme in the context of the Israel-Palestine situation - as much as it was, and still is, in the South African context. Naim Ateek (1989:74) establishes this point by stating that justice lies at the heart of the Palestinian problem. He makes it clear that what happened in 1948 and $1967^{\circ}$ is viewed by Palestinians as absolute injustice to them. He furthers the argument by indicating the link to justice in the Bible and the way it is used and politically abused to justify the state of Israel. ${ }^{9}$ We notice similar tendencies in the South African experience where the Bible was misinterpreted by some Afrikaner and Zionist Christians to justify apartheid. It is no accident then that the ecumenical Church declared apartheid a heresy and biblically untenable and that the churches that justified apartheid had to repent and denounce their biblical justification of apartheid in order to be accepted into the ecumenical family. Any theology of resistance must uphold the quest for justice because this is the call of God who is just, merciful and loving.

An investigation into the meaning of justice (tsedeq and tsedaqah) in the Old Testament shows that, in the context of creation, it has wider meaning. Justice for Israel, like all its neighbours in the ancient Near East, manifests itself in the right and harmonious order of creation. In order to understand the peculiar nature of ancient Near Eastern conceptions of justice, it is important to realise that creation does not primarily refer to the origin of the world at the beginning but to a process by which cosmos, order, replaces chaos, not only in nature but in society as well. ${ }^{10}$ Creation therefore encompasses two realms, which for us are usually quite distinct: the realm of nature and the realm of society. ${ }^{11}$

Justice for Israel, then, means at least two things. Firstly, it refers to the just order on society, what today would be called the rule of law. This rule of law, according to Near Eastern conceptions, is not simply enacted through legislation. Law codes, if they want to reflect the just order of God, have to be grounded in creation itself. That means that the mere fact that a government has passed a law does not in itself guarantee the justness of that law. If that law is not in accordance with God's order of justice, that law will be legal but not right, not just. This is precisely what was seen in 7.Justice has a variety of meanings that can be described in three modes or types:
commutative, distributive and social. It is not within the scope of this article to
focus on these debates. The reader is referred to David Hollenbach, the ACCRA
Confession (2004) and the Belhar Confession (1986) for more insight and information on justice.

8.For more information on the origins of the Six-Day War, which was fought between 5 June and 10 June 1967 by Israel and the neighbouring states of Egypt, Jordan and Syria, see www.sixdaywar.co.uk.un-role. It is also important to note that five months after the Six Day War, the United Nations Security Council prepared a resolution (242) which, amongst other things, called for the 'withdrawal of Israel armed forces from territories occupied in the recent conflict' and the 'termination of all claims or sates of belligerency and respect for and acknowledgement of the sovereignty, territorial integrity and political independence of every State in the area and their right to live in peace within secure and recognised boundaries free from threats or acts of force.' See https://en.wikipedia.org.wiki.United_

9.For a more detailed account about the use of the Bible in the Israel-Palestine context, see Naim Ateek (1989:74-114).

10.For a comprehensive discussion on this, see Walter J. Houston (2010:36-54).

11.For a helpful discussion on this, see Duchrow and Liedcke (1987:47-72). 
apartheid South Africa, and it is no less different in the IsraelPalestine situation. The law is used under the guise of 'national security' or 'national interest' but commits all kinds of injustice on the indigenous people of the land. In the case of the State of Israel, this means that the value judgment that determines the good is the value judgment of the (powerful) Israeli Jews. The good for the powerful becomes right and, therefore, law. However, it remains unjust. Paul Tillich (1963) expresses this well:

The justice of a system of laws is inseparably tied to justice as conceived by the ruling group, and this justice expresses both principles of right and wrong and principles by which the ruling group affirms and sustains and defends its own power. The spirit of a law inseparably unites the spirit of justice and the spirit of the powers in control, and this means that its justice implies injustice. (p. 264)

Secondly, where society is part of a universal order, our contrast between nature and society has no meaning. The terms tsedeq and tsedaqah therefore comprise not only justice in the narrow sense of the term but also, in addition, nature and fertility as the following texts clearly demonstrate (Ps 85:12-14; 65:6-14; 72:3-7; Is 11:1-9; 32:15; $45: 8 ; 48: 18 ; 61: 11 ;$ Jr $2: 23)$. Justice must also be extended to nonhuman life. Thus economic policies and systems must also be evaluated socially and ecologically on the basis of their benefit and harm to the well-being of all in our interdependent relationships. The Accra Confession (2004) shows this well by linking economic justice, gender justice and eco-justice.

The God portrayed in scripture is the 'lover of justice': 'The King is mighty, he loves justice - you have established equity; in Jacob you have done what is just and right' (Ps 99:4; cf. Ps $33: 5 ; 37: 28$; 11:7; Is 30:18; 61:8; Jr 9:24). We see in God's dealings with Israel how God seeks justice for his people. In sympathetic response to the groaning of Hebrew slaves (Ex 2:23-24), the God 'who executes justice for the oppressed' and 'gives food to the hungry' (Ps 146:7, NRSV) pushed Moses to become the liberator, smashed the shackles of Pharaoh and led the people to a new homeland. God's deliverance became the paradigm of justice for Israel and continues to be so for us.

The covenants between God and the liberated people were understood largely as God's laws for right relationships. They established a moral responsibility on the part of society and its members to deal fairly with participants in the covenant and to provide for the basic needs of all. They also served as an expression of loyalty to their liberator and as a condition for harmony (shalom) in the community (Is 32:17). Injustice was a violation of the covenant and an act of faithlessness. In the light of the covenant, to know God is to show justice (Je 22:13-16; Mi 6:8). Indeed, justice in the prophetic tradition is a spiritual discipline, an act of worship, without which the value of other spiritual disciplines prayer, fasting, sacrifice - are negated (Is 58:1-10; Hs 6:6; Am $5: 21-24)$.
Faithfulness to covenant relationships demands a justice that recognises special obligations, 'a preferential option' to widows, orphans, the poor, and aliens, in other words, the economically vulnerable and politically oppressed (Ex 23:6-9; Dt 15:2-11; 24:14-22; Jr 22:16; Am 2:6-7; 5:10-12). This tradition of concern for the weak and poor was embodied in the idea of the Jubilee Year (Lv 25). The Jubilee Year prevented unjust concentrations of power and poverty by requiring the return of property every 50 years. Similarly, the Year of Release (Dt 15:1-18) provided amnesty for debtors and liberation of indentured servants every seven years.

Justice is a very strong biblical theme that a Christian is called to take seriously. The reign of God, the central theme in Jesus 'preaching, should probably be understood as the fulfilment of the prophetic vision of justice and other dimensions of love (Mt 5:3-12; Lk 6:20-31). Jesus incarnates concern for the rights and needs of the poor, befriending and defending the dispossessed and outcasts. For instance, the Magnificat of Mary (Lk 1:52-53) and Jesus' reading from Isaiah (Is 61:1-2) in the temple (Lk 4:16-21) stress social and economic justice; they seem to be attempts of the early Church to define the exemplary ministry of Jesus and the ministry of the Church itself as the pursuit of justice. The suffering servant, with whom the Church traditionally has identified Jesus, is the one who proclaims justice to the nations (Is 42:1-4; Mt 12:18).

Justice then is at the ethical core of the biblical messages. Hence, it is a moral imperative for Christians, especially in our time. Human beings, as moral agents and agents of social changes, possess the power to make positive moral choices and engage in liberating action aimed at the transformation of society in accordance with the moral norm of justice. Justice demands that we focus especially on meeting the needs of the poor and oppressed, both domestically and globally. Economic policies that allow the rich to get richer and the poor to get poorer are not to be tolerated. Economic policies that enable some to get more benefits and others to be deprived must be confronted and resisted with all perseverance. The struggle for social justice is the transformation of existing structures of state, economic order and society so that the poor and oppressed may become full participants in the total life of society. Humankind must thus be actively, radically involved in the creation of the just society. In harmony with divine purpose, the human being (especially the Christian) must be radically involved in the struggle for justice and willing to suffer courageously for the redemption of the human community. This is clearly expressed in a famous sentence from the document produced by an international Synod of Bishops in 1971, Justice in the World, (quoted in Thompson 1997):

Action on behalf of justice and participation in the transformation of the world fully appear to us as a constitutive dimension of the preaching of the Gospel, or, in other words, of the church's mission for the redemption of the human race and its liberation from every oppressive situation. Working for justice is not peripheral or optional, but rather central and essential for a life lived in relationship with God. Faith affects every aspect of 
the believer's life, including the social, cultural, economic and political dimensions. Our faith is not just a weekend obligation, a mystery to be celebrated around the altar on Sunday. It is a pervasive reality to be practiced in homes, offices, factories, schools, and businesses across our land. (p. 188)

To sum up then, justice is a process whereby injustice is overcome, exploitation lifted, oppression removed, rights restored and livelihood assured. The demand for justice permeates all social action, social relationships and social structures. Whatever we do in the struggle for justice, our concrete action should be seen as directed toward social transformation. In other words, there needs to be a vision of an alternative society. What does this mean in the context of the Israel-Palestine conflict?

According to Israel's Declaration of Independence, the following is stated (quoted in Ateek 2008):

[The state] will promote the development of the country for the benefit of all its inhabitants; will be based on the principle of liberty, justice and peace as conceived by the Prophets of Israel; will uphold the full social and political equality of all its citizens, without distinction of religion, race, or sex; will guarantee freedom of religion, conscience, education and culture. (p. 162)

From what we have shown above, it can clearly be established that Israel is far from embracing such a vision. In addition to transforming its political goals, Israel needs a new theology, one 'based on the principle of liberty, justice and peace as conceived by the Prophets of Israel; [that] will uphold the full social and political equality of all its citizens' (Ateek 2008:162). In this regard, Ateek advocates the call for a Palestinian theology of liberation, pointing out that such a theology 'is a way of speaking prophetically and contextually to a particular situation, especially where oppression, suffering, and injustice have long reigned' (ibid:6). Such a theology is grounded in the nature and character of God, offers resistance to injustice, holds out hope to the suffering and oppressed and calls the Church into action (Kairos Palestine 2009)). The Kairos Document (1985) in South Africa adequately expressed this in its critique of 'state theology' and 'church theology' and called for a 'prophetic theology' that takes sides with the poor and oppressed. The CWM theological statement 'Mission in the Context of Empire' (CWM 2010) also called for a resistance to empire, further stressing the need for a theology of resistance which opposes injustice, sides with the poor and oppressed, works for the fullness of life for all and advocates hope. In my opinion, a theology of resistance has three essential characteristics: (1) It is prophetic as it speaks truth to power, (2) it is positional in that it takes sides with the poor and oppressed, and (3) it is transformative as it works for change in a particular context whilst holding out hope. This is what the theology of liberation proposes to do in the Israel-Palestine context.

In the context of Israel-Palestine, justice would require that Israel respects and implements international laws, returns to the Palestinians some of the land it confiscated in the name of Zionism, accepts Palestinians as partners and sharers of the land and upholds human dignity and rights. Furthermore, all concerned must put an end to violence, war and conflict. This is what is referred to as just peace, which simply means that one cannot have peace without justice. Shalom is obviously part of humanness in all stages, forms and manifestations of life; it means the intactness or wholeness or integrity of a community (Duchrow 1987:113). The sad tendency is to use military might, as was the case in South Africa and also is the case in Israel-Palestine, to secure peace. This is translated into the acquisition of new territory and the subjugation of its habitants. However, the peace is only temporary because it is unjust peace. Peace would only last until those who are weak become powerful enough to challenge the force of the oppressor. This is what we have seen in South Africa under apartheid and what we now see in Israel-Palestine.

Israel and Palestine must be prepared to work towards the acceptance and implementation of democratic processes and structures, whether it be a 'One-State' or 'Two-State' solution. ${ }^{12}$ Ateek (2008:168-170) argues quite passionately for a 'Two-State' solution whilst the emerging view today seems to be the 'One-State' solution. It is not our intention to get into this debate except to say that justice requires the implementation of democratic structures and practices. However, justice is not an end in itself, it must lead to reconciliation, forgiveness and healing. This is what I shall focus on in the next section.

\section{Reconciliation and healing}

South Africa has taken initiatives to foster reconciliation and healing within the nation. Nelson Mandela and others who were imprisoned by the apartheid regime surprisingly showed forgiveness and worked for reconciliation and healing rather than vengeance and retribution. Whilst there are critics of this position, it cannot be denied that much is being done to bring the people of South Africa together. Reconciliation is an important theme in the Bible. It is a concept related to forgiveness but with a different goal. The biblical word for reconciliation means 'to come back together with'. It refers to the repair and restoration of a broken relationship which is grounded in the action of God through the death and resurrection of Jesus Christ (Eph 2:14-18). Whereas forgiveness rests with the giver, reconciliation is 'a two-way street' - it must involve both parties. ${ }^{13}$ It implies a desire to continue a relationship, recognising that both parties need to work together to get along.

Reconciliation in divided societies must be understood as a fundamentally transformative process, one that requires 'changing the motivations, goals, beliefs, attitudes and emotions of the great majority of society members regarding the conflict, the nature of the relationship between the parties,

12.Naim Ateek (2008: 1168-170) argues quite powerfully for a 'Two-State' solution. For a discussion on a 'One-State' solution, see Abunimah (2005).

13.There is often a debate on reconciliation and forgiveness. Which action should come first? Some insist that forgiveness precedes reconciliation whilst others argue that forgiveness is the ultimate goal. Our task is not to focus on this debate but to merely make the point that reconciliation and forgiveness are actions but to merely make the point that reconciliation
necessary in the overall intention of receiving peace. 
and the parties themselves (Aiken 2009:19). Martha Minow (1998) states that, in the context of mass violence, justice must walk the path between the opposing poles of vengeance and impunity - a path that acknowledges the wrongness of the harm to victims, assigns responsibility to perpetrators for their actions and recognises the need to work towards repairing past injustices. The biblical call for forgiveness and reconciliation is not to forget about the past but to remember never to do injustice again.

In order to look at what can be done in the context of IsraelPalestine, I shall now attempt to reflect on some practical things that can be undertaken to foster reconciliation, forgiveness and healing. I refer to these suggestions as theological praxis - the ability to translate theological thinking into action. In order to illustrate this, I shall draw from transitional-justice theorists. ${ }^{14}$ There is a growing consensus amongst conflict transformation theorists as to what successful reconciliation might entail in deeply divided societies such as Israel-Palestine. Generally speaking, they have identified five such indicators (Aiken 2013:20-22).

Firstly, reconciliation is marked by social learning that develops mutual trust amongst former enemies. It is very difficult to encourage trust building in broken relationships. In the context of Israel-Palestine, trust is diminished in the midst of violence, the failure to keep agreements, constant land occupation and the inability to find a way forward over so many years. It is commendable that Christians and Muslims are working together in trustable relationships to work for peaceful solutions to the Israel-Palestine conflict. This is also one of the memorable visions of the struggle against apartheid. It brought together people from many different faiths to unite in their actions against the evils of the apartheid regime. In the context of Israel-Palestine, Christians need to work hard in drawing Israeli people, especially leaders, into the circle of trust. It is usually such relationships that help to change distrust and suspicion into positive ways of seeking change. However, it should be noted that repentance is a precondition for change; it must precede reconciliation and forgiveness. In the conflict between Israel and Palestine, repentance would correspond to an admission by the government of Israel of the injustice it has dealt to Palestinians in its confiscation of land, its violation of human rights and its systems of domination and oppression (Ateek 2008:184). Such repentance, combined with a willingness to do justice and offer reparation, could open the way to reconciliation and forgiveness. In this, the Church has a very definite role to play.

Secondly, reconciliation in divided societies involves processes of social learning that develop a broader sense of collective identification in which the cognitive boundaries of the Self are expected to include the Other, replacing previous divisions with a sense of shared identity, friendship, trust

14.Transitional-justice theorists have provided some very helpful practical suggestions to bring about transformation in conflict situations. My focus in using some of these is intended to offer practical suggestions as to what Christians can do in these is intended to offer practical suggestions as to what Christians can do in
similar situations. In attempting this, I shall draw mostly from the work of Nevin T. similar situations. and common interest. The Bible is very clear about putting the interest of others first. Paul, writing in Philippians 2:3-4, states:

Do nothing out of selfish ambition or vein conceit, but in humility consider others better than your selves. Each of you should look not only to your own interests, but also to the interests of others.

Likewise there are many passages in the Old Testament that speak about taking care of the poor, vulnerable and oppressed people. ${ }^{15}$ Clearly, Israel has not taken God's call seriously in their treatment of and disrespect for Palestinians in their own land. It is quite alarming that this is so, given their own history of persecution at the hands of the Nazis. It seems that, after this experience, their survival instinct has driven them to imperialistic tendencies. Referring to the South African experience, Praeg (2000:299) states that, concerning the inclusion of the 'we' in the act of judgment, this historical dimension of the traditional dictum for identity places the contemporary $I$ in a relationship with its history that is both ethical and necessary. The Church must continue to exercise a prophetic call for justice so that 'fullness of life' is availed to the Other.

Thirdly, the kind of reconciliatory social learning required in divided societies must also include a corresponding change to the antagonistic societal beliefs that enemies hold about one another and that reinforce their relationships of enmity. Reconciliation requires an extension of the boundaries of moral community amongst former antagonists such that members of the Other are effectively 'rehumanised' (Aiken 2009:21). In essence, this entails the development of a more equitable moral order that values difference but also recognises a common humanity amongst former enemies - the notion that Self and Other should be accorded equal moral worth and are therefore entitled to the same ethical considerations. Most notably, this process involves replacing the previous 'culture of violence' with a new 'culture of human rights' under which both Self and Other are perceived to be equally entitled to fundamental human-rights protections (Aiken 2009). This is evidently what we saw in South Africa. The focus on human rights led to the establishment of processes and actions that brought people and groups together to help pave the way for democracy, nation-building, rehumanisation and, ultimately, reconciliation and healing. In the Israel-Palestine situation, we need to find ways to deal with the dehumanisation of people over such a lengthy period in time. However, this can only work when all concerned are prepared to genuinely shift from a 'culture of violence' to a 'culture on human rights'. This is seriously needed in the context of Israel-Palestine, and the Church can play a significant role in enabling this shift, not just because it is capable of so doing but, most significantly, because the Gospel calls it to proclaim and work for justice.

Fourthly, successful reconciliation is distinguished by social learning that leads to perceptions of the illegitimacy or 'unthinkability' of the use of violent force to resolve future disputes amongst former enemies. Reconciliation enables us 15. Refer to passages indicated in the section on Justice. 
to move from a war-system, characterised by deeply divided, hostile and violent relationships, into a peace-system, characterised by just and interdependent relationships with the capacity to find non-violent mechanisms for expressing and handling conflict (Aiken 2009). It is a vision of former enemies becoming integrated to the point that there is a real assurance that the members of that community do not fight each other physically but will settle their disputes in some other way. Ateek, who takes the position of non-violence, argues for this in spite of the fact there are others who have come to believe that passive resistance does not work. In South Africa, the Kairos Document established that there is a place for engaged action based on the theory of a 'Just War'. However, in the South African context, it is clear that strides and changes have been made when people, whether forced or willingly, come to the table and dialogue the way forward toward just peace together. The challenge, of course, is getting them to that place. The Church needs to find effective ways in achieving this, and it needs to call on the international world, including world-wide ecumenical bodies, to intervene and assist. This is being done in Israel-Palestine, but more effort needs to be put into it. Part of the struggle is that Christian organisations are often split on their positions on the IsraelPalestine situation. We need a common voice with joint efforts to resist injustice. This would also require challenging Christian Zionism and the biblical justification that usually comes with it.

Fifthly, changes in structural and material conditions are also considered necessary components of social learning and successful reconciliation in divided societies. Reconciled relationships cannot be sustained effectively if gross disparities in economic well-being or inequitable access to social and political rights persist. This is still a problem in South Africa. Although we have a democratic government, the conditions of poor and needy people have not really changed since the demise of apartheid. The ongoing municipal protests and turmoil in the mining industry are some of the indications of the need to shift and address economic imbalances in South Africa. Former enemies' entrenched animosities will not fade easily with the passage of time but will rather require extended reconciliation processes in order to be challenged and overcome (Staub 2001:17). It does not happen in just one Truth and Reconciliation Commission (TRC) exercise as we did in South Africa. Reconciliation and healing is an ongoing process. ${ }^{16}$ Truth-recovery and truth-telling is an important dimension for reconciliation and healing, but this must also be accompanied by initiatives to redress the evils and deprivation of the past. This is where the TRC ultimately failed in the South African situation.

\section{Conclusion}

In this study, I have shown that a comparison between the Israel-Palestine conflict and the South African apartheid experience is, indeed, justifiable. Further, I offered a theological critique of the situation in Israel-Palestine by focusing on the need for justice and reconciliation as in the experience of South Africa. I pointed out that the (ecumenical) Church in South Africa contributed immensely to the dismantling of apartheid by taking sides with the majority of poor and oppressed people, refuting apartheid as a heresy and biblically untenable, prophetically speaking out and acting against injustice, mustering the support of the international world, getting politicians to talk, participating in the TRC and helping in the reconstruction and development of the new South Africa. The Israel/Palestine conflict is still with us and seems to get worse by the days. The Church in Israel-Palestine needs to continue with a similar role. It needs to continue to call on the intervention and support of the international world as it raises awareness and communicates the truth of what is happening in its context. It needs to work for justice and reconciliation as it seeks to bring people together, resist the empirical ambition of Israeli Jews and pave the way for a new alternative society in Israel-Palestine where there is just peace and fullness of life for all.

\section{Acknowledgements Competing interests}

The authors declare that they have no financial or personal relationships which may have inappropriately influenced them in writing this article.

\section{References}

Abunimah, A., 2005, One Country: A Bold Proposal to End the Israeli-Palestinian Impasse, Metropolitan Books, New York, NY.

Aiken, N.T., 2013, Identity, Reconciliation and Transitional Justice Overcoming Intractability in Divided Societies, Routledge, New York, NY.

Aiken, N.T., 2009, 'The (Re)Construction of a Culture of Human Rights: Transitional Justice and Human Security', Human Security Journal 8, 10-18.

Al-Rimmawi, H., 2009, 'Spatial Changes in Palestine: from Colonial Project to an Apartheid System', African and Asian Studies 8, 375-412.

Ateek, N.S., 1989, Justice, and only Justice: A Palestinian Theology of Liberation, Orbis Book, Maryknoll, New York, NY.

Ateek, N.S., 2008, A Palestinian Christian Cry for Reconciliation, Orbis Books, New York, NY.

Bakan, A.B. \& Abu-Laban, Y., 2010, 'Israel/Palestine, South Africa and the 'One-State Solution': The Case for an Apartheid Analysis', Politikon: South African Journal of Political Studies, http://www.tandfonline.com/loi/cpsa20

Boesak, A., 2005, The Tenderness of Conscience: African Renaissance and the Spirituality of Politics, Sun Press, Stellenbosch.

Boycott, Divestment and Sanctions (BDS) Newsletter, 2013, Nelson Mandela speaking on Palestine, BDS South Africa, Johannesburg.

Carey, R., 2001, The New Intifada: Resisting Israel's Apartheid, Verso, New York, NY.

Cliff, T., 2000, A World to Win: Life of a Revolutionary, Bookmarks, London.

Cook, J., 2006, Blood and Religion: The Unmasking of the Jewish and Democratic State, Pluto, London.

Council for World Mission, 2010, Mission in the context of Empire: CWM Theology Statement, CWM Publication, London.

Davis, U., 2001, Israel: An Apartheid State, Abridged Edition, Media Review Network, South Africa.

Duchrow, U. \& Liedke, G., 1987, Shalom: Biblical Perspectives on Creation, Justice \& Peace, WCC Publications, Geneva.

Falk, R.A., 2014, Palestine: The legitimacy of hope, Just World Pub. Co., Charlottesville.

Farsakh, L., 2002, 'Palestinian labor flows to the Israeli Economy: A Finished Story?' Journal of Palestinian Studies, 32(1), 13-27.

Farsakh, L., 2005, 'Independence, Cantons, or Bantustans: Whither the Palestinian State?' Middle East Journal, 59(2), 230-245.

Goldstone, R.J., 2011, 'Israel and the Apartheid Slander', New York Times, October 31. 
Hollenbach, D., 1988, Justice, Peace \& Human Rights: American Catholic Social Ethics in a Pluralistic Context, Crossroad, New York, NY.

Harlow, B. Apartheid or Not Apartheid? The Russell Tribunal on Palestine, South Africa, November 2011, Sage, UK.

Housten W.J., 2010, Justice-The Biblical Challenge, Eqinox, London.

Human Science Research Council Report, 2009, Democracy and governance programme Middle East project, Cape Town.

Joseph, B.M., 1954, Besieged Bedfellows: Israel and the Apartheid, Greenwood Press, New York, NY.

Minow, M., Between Vengeance and Forgiveness: Facing History after Genocide and Mass Violence, Beacon Hill Press, Boston, MA.
Pollak, J.B., 2009, The Kasrils Affair: Jews and Minority Politics in Post-Apartheid South Africa, University of Cape Town Press, Cape Town.

Praeg, L., 2000, African Philosophy and the Quest for Autonomy: A Philosophical Investigation, Rodopi B.V., Amsterdam.

Rodinson, M., 1973, Israel: A Colonial-Settler State? Pathfinder, New York, NY.

Shore, M., 2009, Religion and Resolution: Christianity and South Africa's Truth and Reconciliation Commission, Ashgate Publishing Limited, England.

Staub, E., 2001, 'Individual and Group Identities in Genocide and Mass Killing,' in R.D. Ashmore, L. Jussim and D. Wilder (eds.), Social Identity, Intergroup Conflict, and Conflict Reduction, Oxford University Press, Oxford.

Thompson, J. M., 1997, Justice \& Peace: A Christian Primer, Orbis Books, New York, NY. 